\title{
SPINOZISM IN SOCIAL SCIENCE
}

\section{Affiliation}

Alexander Xavier Douglas

University of St Andrews, Department of Philosophy

St Andrews, Fife, Scotland, UK

axd@st-andrews.ac.uk

(+44) 01334464337

\section{Synonyms (if possible)}

\section{Related Topics}

Affects; Emotions; Psychology; Social Explanations; Society

\section{Definition/Introduction}

In the Preface to Part Three of the Ethics Spinoza proposes to "consider human actions and appetites just as if it were a question of lines, planes, and solids" (3pref, II/138). Descartes had made impressive achievements in physics by applying the same thinking: "The only principles which I accept, or require, in physics are those of geometry and pure mathematics; these principles explain all natural phenomena" (Principles, 2.64; AT 8a.78 / CSM 1.247) (see Descartes' Mechanical Philosophy). Should Spinoza's proposed 'geometry of affects' be regarded as an early attempt at what we would call a social sciencei.e., the systematic study of how humans behave in society? If so, should his approach to social science be regarded as rationalist or empiricist? As naturalistic or non-naturalistic? There is a good deal of ambiguity here; as Yves Citton and Frédéric Lordon put it: "To conceive the relation between the philosophy of Spinoza and the development of the social sciences requires at once acrobatics and evidence" (Citton and Lordon 2010, 19).

\section{Main Text}

\subsection{A Geometry of Affects}

What does Spinoza mean by "human actions and appetites"? What does he mean by "a question of lines, planes, and bodies"? Actions and appetites occur in the realm of concrete nature. Lines, planes, and solids inhabit an abstract realm of mathematical objects. They are not to be observed in nature, though things in nature might resemble them to varying but always infinitely imperfect degrees. Their properties, at least relative to some geometry, are determined a priori through a deductive system. Concrete things, by contrast, are brought about through causal processes and known by observation and experiment. Abstract things exist, if we are constructivists about them, in virtue of what is provable in a formal system. Or, if we are Platonists, they inhabit some realm that is separated by a metaphysical gulf from concrete objects in time and space.

One of the most distinctive features of Spinoza's philosophy, however, is that it plays loose with this distinction. There are problems with it in any case. There is what Eugene Wigner named the "unreasonable effectiveness of mathematics in the natural sciences" (Wigner 1960). In Descartes' 
physics, for instance, physical objects move in straight lines unless interfered with. This applicability of a concept from formal geometry to concrete physics is a mysterious intrusion of the realm of the abstract into that of the concrete. One reading of Descartes' Meditations takes it as in large part an attempt to make epistemological sense of this (Carriero 2008). For Descartes, as for later physicists, a theory of physics is simply a mathematical structure defined over a domain of abstracta: a set of equations expressing laws of nature as relations among mathematical objects (see Descartes' Mechanical Philosophy; Mechanism: Mathematical Laws). Somehow the abstract model relates to concrete reality in such a way as to yield understanding of the latter.

Spinoza is aware of how much more far-fetched it seems to claim that human psychology could be similarly understood by comparison to a formal, abstract object. Hobbes had proposed that "were the natures of human actions as distinctly known, as the nature of quantity in geometrical figures, ... mankind would enjoy such an immortal peace that . . there would hardly be left any pretence for war" (Hobbes 1983, §6) (see Hobbes' Theory of the Emotions in Scientific Context). It is unclear that he found this a realistic hope. While the physical interactions of bodies have an apparent systematic character, justifying their treatment through mathematical methods, human passions look like a mere mess. Can there be any structure to them at all? Spinoza notes that:

to those who prefer to curse or laugh at the affects and actions of men . . . it will doubtless seem strange that I should undertake to treat men's vices and absurdities in the geometric style, and that I should wish to demonstrate by certain reasoning things which are contrary to reason, and which they proclaim to be empty, absurd, and horrible (Ethics 3pref).

But those who wish to understand rather than to curse or laugh will, Spinoza promises, find as much formal structure in human affects as physicists find in the motion of bodies. This follows, indeed, from his view that the mind and the body are one and the same thing expressed under two different attributes (Ethics 2p7c) (see Mind, and Body). Affects are, under the attribute of thought, what certain bodily events are under the attribute of extension. If the latter can be understood by way of a mathematical structure, then so must the latter. At least I see no reason to doubt that mathematical structure is preserved across attributes. There must be a geometry of affects just as there is a geometry of motion. This is what Spinoza seeks to build.

The core of Spinoza's geometry of affects is the conatus - the striving by which, he tells us at Ethics 3p6, each thing strives to persevere in its being, insofar as it can (see Conatus). The final clause reduces the whole doctrine to near-triviality. Even a thing that falls apart as soon as it is generated can be said to strive to persevere in its being insofar as it can; that just turns out to be not very far. The same accusation of triviality can be made of Descartes' laws of motion: to know that bodies move in straight lines unless interfered with, e.g., is to know almost nothing about how any given body will move, since bodies in the real world are always interfered with a great deal. The theory does, however, give us a model of explanation: any given motion will have to be explained in terms of bodies moving in straight lines and transferring their motion to one another. It must be tractable in terms of vector algebra. Likewise Spinoza's conatus theory gives us a model of psychological explanation. Any given affect must be explained in terms of a subject's fundamental striving to persevere in being - which manifests in conscious experience as desire (3p9) - combined with her interactions with other things. Each of these is animated by its own central striving. Spinoza identifies striving as the actual essence of each thing (3p7), while holding that a bodily affection and the corresponding affect always expresses the nature of both the affecting and affected person (2p16). Psychology would thus seem also to be tractable in terms of a sort of psychic vector algebra: a psychological affect that drives action is like the vector sum of a group of strivings.

Although Descartes uses the term "conatus" in outlining the inertial principle at the heart of his physics, it is hard to see how this could be the source of the conatus theory on which Spinoza bases his geometry of affects. As Daniel Garber has pointed out, no merely inertial principle could explain how, according to Spinoza, humans not only fail to actively destroy themselves, they also resist hostile forces from the outside and seek out possible advantages (Garber 1994) (see Conatus). At any rate, once the 
fundamental theory is in place, Spinoza is able to define all the affects in terms of conatus. Conatus itself is appetite. Conatus plus consciousness is desire (Spinoza does not tell us much about what consciousness is - Nadler 2008). Joy is an increase in the power by which one strives. Sadness is a reduction in that power. All the other affects, Spinoza tells us, arise from these three (3p9s), along with certain ideas of things. Love, for instance, is joy accompanied by the idea of an external cause.

\subsection{Spinoza and Predictive Social Science}

Spinoza's geometry of affects gives us some scope for controlling the passions. If I want to stop loving $\mathrm{X}$ and love $\mathrm{Y}$ instead, the geometry of affects helps me to know what is required: I must form an idea of $\mathrm{Y}$ rather than of $\mathrm{X}$ as the external cause of my joy. Beyond this therapeutic purpose, however, is there any sense in which Spinoza's geometry of affects could give us new predictive power with respect to human social behaviour? This is a dominant goal in social science; otherwise it is not entirely clear what the purpose of the exercise is (Winch 1990).

The idea of a predictive social science supports an ideal that became increasingly prominent during the Enlightenment. As natural science was allowing humans to control and harness the power of nature, so a naturalistic social science might allow them to control and harness their own psychological energy, realising social ends that they could not have imagined achieving before. Many Enlightenment thinkers took the idea that there may be laws of psychology mirroring the laws of physics to support their reformist political and social project. Helvétius wrote that "we should treat morals like all the other sciences, and construct a moral science like experimental physics" (Helvétius 1758, i-ii). Elsewhere he insisted that: "If the physical universe is subject to the laws of motion, the moral universe is no less subject to the laws of interest" (Helvétius 1758, II.2). The Baron d'Holbach proclaimed that "Morals is the science of the relations that hold among the minds, the wills, and the actions of men, as geometry is the science of the relations that hold among bodies" (d'Holbach 1771, I.xi). He sounds particularly Spinozistic in passages such as the following:

Conservation ... is the common point to which all the energies, all the powers, all the faculties of beings, seem continually directed. ...[M]oralists call it in man, self-love, which is nothing more than the tendency he has to preserve himself - a desire of happiness - a love of his own welfare - a wish for pleasure - a promptitude in seizing on every thing that appears favourable to his conservation - a marked aversion to all that either disturbs his happiness, or threatens his existence.... (d'Holbach 1771, I.iv)

But one significant problem with associating Spinoza with this project of naturalistic social science is that such a science would, on the reckoning of its proponents, be broadly empiricist, whereas Spinoza's social science has a deeply rationalistic character. At least, the successful methods of physics, which the Enlightenment figures hoped to extend to the social world, were decidedly empirical; d'Holbach for instance wrote that:

Nature acts by simple, uniform, invariable laws, which experience places us within range of knowing. It is by our senses that we are tied to the universal nature. It is by our senses that we have it in experience and discover its secrets. As soon as we abandon experience, we fall into the vacuity into which our imagination misleads us ( d'Holbach 1771, I.i).

It is very hard to make the case that Spinoza's geometry of affects is grounded in experience. The fundamental law, that each thing strives to persevere in being, is justified, not by any appeal to experience, but to metaphysical principles of a highly abstract nature (Curley 1973; Garber 1994; Lin 2004). While Spinoza occasionally claims that experience teaches the psychological doctrines he expounds (e.g. 3p32s), these claims appear as side notes further bolstering a theory whose primary justification lies elsewhere.

Nor is it obvious how it could even be empirically tested. It tells us that a subject's desire is her consciousness of striving to persevere in being. Does the consciousness represent the striving accurately? Even if it does, what is it that people strive to persevere in being? If our fundamental striving is only to 
retain some bare biological life, this seems incapable of explaining as much of our psychology as Spinoza aims to explain - unless we wish to commit to the radical view that every impulse and quirk of our personality arises from a bare survival instinct. On the other hand, if we strive to be something more specific, Spinoza gives us few hints about how to work out what this more specific thing is in each case. Also, since our ideas can be both erroneous and truthful, we can be right or wrong about, e.g., the cause of our increase in power. The upshot seems to be that Spinoza's theory is empirically unfalsifiable. Does seeing a subject run into the lion's den refute the theory? No. Perhaps this behaviour is necessary to preserve her under the particular strange description under which she aims to persevere. Or perhaps her ideas are so erroneous that if they were true her behaviour would be perfectly consistent with striving to persevere. It is no easier to see how the theory can be empirically verified than it is to see how it can be empirically falsified.

To recognise this is to apprehend the vast gulf between Spinoza's geometry of affects and the Enlightenment project of a naturalistic, predictively powerful social science. Given that empiricism is widely recognised as being indispensable for a predictively successful theory, we might suppose that Spinoza's geometry of affects serves some purpose other than prediction and precise social control. This does not mean that it should not qualify as a social science; it might be, as Joan Robinson proposed, that "The function of social science is quite different from that of the natural sciences - it is to provide society with an organ of self-consciousness" (Robinson 1970, 120).

\subsection{Spinoza and Non-Naturalistic Social Science}

Yves Citton and Frédéric Lordon have noted that Spinoza is too naturalistic - too committed to the idea that human action must be explained by the same laws of nature that apply to non-human things - to be associated with the ideal of social science in the tradition running roughly from Durkheim through Bordieu. The social sciences in this tradition "have fought ceaselessly, and not without good reasons, against all tendencies to extrapolate the laws of the historical world from "laws of nature" (Citton and Lordon 2010, 23). And "Spinozist naturalism cannot appear as anything but a monstrous regression [to] those who have constructed a proper domain for social science by separating it from the physical sciences and by affirming the nature/culture discontinuity" (Citton and Lordon 2010,23). Citton and Lordon suggest, however, that much of the motivation for insisting on this discontinuity comes from a fear of an excessively reductive naturalism. Spinoza's naturalism gives no grounds for this fear:

One must underestimate, and vastly, the infinite productivity of nature in Spinoza, and above all the complexity of its productions, to imagine that a naturalistic position would be necessarily condemned to those intellectual aberrations that the social sciences have justly taken heart to denounce - "human nature" as a unique standard, the sacralisation of relations of bare force, a primitive sociobiology, a renunciation of politics, etc. (Citton and Lordon 2010, 24)

For a concrete example, we might take Spinoza's explanation of sacrifices in the Tractatus Theologico-Politicus. Spinoza tells us that "the Patriarchs sacrificed to God, not because some divine legislation commanded it, nor because they had been instructed in the universal foundations of divine law, but only because it was the custom at that time" (Spinoza 2016, 2:143, III/73). The explanation seems to bottom out at an appeal to custom. This seems very much in line with anti-naturalistic social science, which defines itself by regarding human institutions, cultures, customs as primitive explanantia, irreducible to 'natural' causes such as, e.g., biological processes or neurological events. Yet Spinoza insists, in the Preface to Part 3 of the Ethics, that humans follow rather than disturbing the natural order. Can this thought be reconciled with his apparently anti-naturalistic explanation?

It is noteworthy that, unless there is action at a distance, social facts of any sort must pass through psychological causes (Rosenberg 2012, 182). We have seen how Spinoza can be a naturalist about psychology: actions and appetites are subject to a geometrical science that is the counterpart to the physical science that studies their manifestations under the attribute of extension. To be able to naturalise 
the social facts to which he refers, he need only be able to explain them in psychological terms. Does he have the resources for doing so?

I believe that he does. First, consider an argument that any social fact must be ultimately explained in terms of something non-social. E.g., I sacrifice to God because my parents did so. They sacrificed because their parents sacrificed. It was always done this way, we say, except of course this cannot be: the tree of parents cannot branch back forever. At the terminus of a branch, we must find somebody sacrificing for some reason other than custom. We need a non-social explanation for this, unless we treat the original act as simply inexplicable. But to admit a non-social explanation at one point stirs the temptation to dispense with the social explanation altogether. If neurology, biology, or psychology can explain what the agent at the end of the branch does, why not the whole branch? Hence, perhaps, the uneasy tension that comes through in Citton and Lordon's discussion quoted above. The tension is between those with naturalistic ambitions - sociobiologists, for instance - and those who, wishing to preserve a space for social science in its own right, feel they must maintain the absolute autonomy of social explanation.

An attractive middle course is to find a theory that marries together the social and the psychological. Spinoza achieves this to a remarkable degree (Douglas 2016). As a matter of individual psychology, we are driven by the fundamental striving to persevere in being. But, again, it is not obvious what description we wish to persevere in being under. Which features of ourselves do we wish to retain? Which features are we willing to have changed, in order to persevere or even become a truer version of ourselves? For Spinoza, I believe, the answer for many of us lies in the exemplars we find all around us. Which of the others around us seem like successful examples of human life? That is what we ought to try to be. And so we have the impulse to emulation: "the desire for a thing which is generated in us from the fact that we imagine others like us to have the same desire" (3p27s). More than this, our insecurity leads us to crave emulation from others. What surer confirmation could we have that we are on the right track with our striving than to witness others striving to be like us? And so we develop ambition: "each one of us strives, so far as he can, that everyone should love what he loves, and hate what he hates" (3p31c). Ambition and emulation link psychological facts to social facts. It is facts about our individual psychology that explain why there should be ambition and emulation: why humans ought to imitate each other, willingly and with encouragement from those they imitate. From this point social facts can be explained entirely in terms of imitation.

At the origin of a series of imitation there must exist an action that is not an imitation. But the action itself could be quite arbitrary. The first sacrificer might have thought very little about what she was doing; she might have been trying something out on a mere whim. From here ambition and emulation take over to explain the entrenchment of the social fact. The non-social explanation makes only a minimal contribution to the explanation of the social phenomenon. In this way Spinoza is able to maintain a theory ultimately grounded in a naturalistic psychology while preserving a significant degree of autonomy to properly social explanations.

\section{Cross-References}

Conatus; Descartes' Mechanical Philosophy; Emotions, Passions, and Affections; Hobbes, Thomas; Hobbes' Theory of the Emotions in Scientific Context; Mechanism: Mathematical Laws; Mechanism: Modelling; Stoicism; Mind, and Body; Psychology; Psychology, and Ethics (Moral Psychology); Psychology, and Physiology (Anatomy); Spinoza and the Sciences; Social Theories of Self/Mind; Soul (Emotions); Will (Emotions) 


\section{References}

Carriero J (2008) Between Two Worlds: A Reading of Descartes's Meditations. Princeton University Press, Princeton

Citton Y, Lordon F (2010) Un devenir spinoziste des sciences sociales. In: Citton Y, Lordon F (eds) Spinoza et les sciences sociales: De la puissance de la multitude à l'économie des affects. Éditions Amsterdam, Paris, pp 19-68

Curley E (1973) Spinoza's Moral Philosophy. In: Grene MG (ed) Spinoza: A Collection of Critical Essays. Anchor Books, Garden City, pp 354-76

Douglas A (2016) The Affects. In: Campos AS (ed) Spinoza. Imprint Academic, Exeter, pp 106-117

Garber D (1994) Descartes and Spinoza on Persistance and Conatus. Studia Spinozana: An International and Interdisciplinary Series 10:

Helvétius C-A (1758) De l'Esprit. Durand, Paris

Lin M (2004) Spinoza's Metaphysics of Desire. Archiv für Geschichte der Philosophie 86:21-55

Nadler S (2008) Spinoza and Consciousness. Mind 117:575-601

Paul Henri Thiry d'Holbach (1771) Paul Henri Thiry d'Holbach, Système de la nature, ou des lois du monde physique et du monde moral. Frantext, London

Robinson J (1970) Freedom \& Necessity: An Introduction to the Study of Society. Vintage Books, New York

Rosenberg A (2012) Philosophy of Social Science: Written by Alexander Rosenberg, 2012 Edition,. Westview Press

Spinoza B de (2016) The Collected Works of Spinoza. Princeton University Press, Princeton

Wigner EP (1960) The Unreasonable Effectiveness of Mathematics in the Natural Sciences. Comm Pure Appl Math 13:1-14 . doi: 10.1002/cpa.3160130102

Winch P (1990) The Idea of a Social Science and Its Relation to Philosophy. Routledge, London 